\title{
Efficacy of Gaseous Ozone Against Paenibacillus Larvae Spores on Hive Materials
}

\author{
Emrah Torlak ${ }^{1}$, Mehmet Kürşat Işık² \\ ${ }^{1}$ Necmettin Erbakan University, Faculty of Science, Department of Molecular Biology and Genetics, Konya, Turkey \\ ${ }^{2}$ Konya Food and Agriculture University, Strategic Research and Development Centre, Konya, Turkey
}

Geliş Tarihi / Received: 13.02.2018, Kabul Tarihi / Accepted: 16.04.2018

\begin{abstract}
American Foulbrood (AFB) is a highly contagious bacterial honey bee disease caused by Paenibacillus larvae. The elimination of P. larvae spores from contaminated hives is a key factor to achieve the long-term success in AFB control. The purpose of this study was to evaluate the efficacy of gaseous ozone in inactivating the P. larvae spores on wooden and plastic hive materials. Untreated pinewood and polyvinyl chloride (PVC) were chosen as representatives for the hive materials. Pinewood and PVC sticks inoculated with a spore cocktail of three P. larvae strains were treated up to $120 \mathrm{~min}$ with two different constant concentrations of gaseous ozone $(9.8$ and $17.1 \mathrm{mg} / \mathrm{L})$ at room temperature. Ozonation at $17.1 \mathrm{mg} / \mathrm{L}$ for $120 \mathrm{~min}$ yielded over the $4 \mathrm{log}$ reduction in the counts of spores on PVC sticks. Whereas, reduction of $2.3 \mathrm{log}$ was obtained on pinewood sticks under the same experimental conditions. Reductions achieved in the levels of P. larvae spores on PVC sticks after 90 and 120 min of ozonation were significantly $(\mathrm{p}<0.05)$ higher than those on pinewood sticks. Our results suggest that gaseous ozone treatment is a promising candidate for the sterilization of plastic hives contaminated with P. larvae spores.
\end{abstract}

\section{Ozon Gazının Kovan Materyalleri Üzerinde Paenibacillus Larvae Sporlarına Karşı Etkinliği}

Key words: Paenibacillus larvae, Spore, Hive material, Ozonation.

Özet: Amerikan Yavru Çürüklüğü (AYÇ) Paenibacillus larvae'nın neden olduğu oldukça bulaşıcı bakteriyal bir bal arısı hastalığıdır. P. larvae sporlarının kontamine kovanlardan eliminasyonu AYÇ'nin uzun süreli başarılı kontrolünde anahtar bir faktördür. Bu çalışmanın amacı ozon gazının ahşap ve plastik kovan materyalleri üzerinde $P$. larvae sporlarını inaktivasyon etkinliğinin değerlendirilmesidir. Kovan materyallerini temsilen işlem görmemiş çam ağacı ve polivinil klorür (PVC) seçilmiştir. P. larvae sporları ile kontamine edilen çam ağacı ve PVC çubukları ozon gazı ile 120 dakikaya kadar iki farklı sabit konsantrasyonda $(9.8$ ve $17.1 \mathrm{mg} / \mathrm{L})$ oda sıcaklığında muamele edilmiştir. PVC çubuklara 120 dakika boyunca $17.1 \mathrm{mg} / \mathrm{L}$ düzeyinde ozon uygulaması spor sayısında 4 log üzerinde azalmaya neden olmuştur. Buna karşılık, aynı deneysel koşullarda çam ağacı çubukları üzerinde $2.3 \log$ azalma elde edilmiştir. PVC çubuklar üzerinde $P$. larvae spor seviyelerinde 90 ve 120 dakika ozonlama sonrasında elde edilen indirgenme değerleri çam ağacı çubukları üzerinde elde edilen değerlerden önemli $(p<0.05)$ düzeyde yüksektir. Sonuçlarımız ozon gazı uygulamasının $P$. larvae sporlarıyla kontamine plastik kovanların sterilizasyonu için umut verici bir aday olduğunu düşündürmektedir.

Anahtar kelimeler: Paenibacillus larvae, Spor, Kovan materyali, Ozonlama.

\section{Introduction}

Paenibacillus larvae, a Gram-positive facultative anaerobe, is the etiological agent of American Foulbrood (AFB), a severe bacterial disease of honey bee brood (Apis mellifera) $[2,11]$. P. larvae has ability to form extremely tenacious endospores when environmental conditions do not favor vegetative bacterial growth. The spores are the only infectious form of pathogen and can infect only the larvae, whereas spores do not cause infection in adult bees upon their ingestion [14, 20, 27]. P. lar- vae spores can survive under environmental stress conditions for an extended period of time, and are resistant to a wide-variety of treatments such as heat, desiccation and chemicals $[10,13]$. A key factor in the control of AFB is disinfection of beehive equipment, especially when apiary is confronted with clinical signs accompanied by extremely high numbers of spores [8].

Wood and plastic are the materials most generally preferred for hive construction due to their advantages of being durable and flexible. Traditional 
decontamination of wooden hive materials for $P$. larvae spores involves a variety of treatments including disinfection with chemicals, scorching with a blowtorch and immersion into molten paraffin. However, options available for plastic hives are limited compared to the range of treatments can be used for wooden hives [9]. Del Hoyo et al. [7] found the dipping of wooden frames in hot paraffin was a very effective disinfection method. However, it should be noted that the manipulation of hot paraffin requires special equipment and heavy duty protective clothing, which the average beekeeper does not have [9]. Dobbelaere et al. [8] reported that complete elimination of $P$. larvae spores on wooden hive materials by disinfectants could only be achieved when they were used at extremely high concentrations. They also reported that the scorching of wood was not satisfactory as it only effective against spores at the surface of material. These disadvantages of the traditional decontamination methods for hives have led to use of alternative treatments such as methyl oxide and gamma radiation. However, these treatments are expensive and generally only available to beekeepers who operate near a treatment facility $[6$, 16].

Gaseous ozone is an environment-friendly and powerful sanitizer due to its potential oxidizing capacity [23]. The regulatory status of gaseous ozone for sanitizing applications has been addressed in several countries. It has been registered as a sanitizer for direct application on surfaces by the US Environmental Protection Agency [1, 12]. Ozone does not require storage, special handling or mixing considerations, and hence it may be considered more practical compared to other chemical sanitizers [4]. Therefore, this study was aimed to evaluate for the first time the efficacy of gaseous ozone against $P$. larvae spores on wooden and plastic hive materials.

\section{Materials and Methods}

\section{Microorganisms and spore suspension}

Two strains obtained from the field and one certified strain (ATCC 9545) of Paenibacillus larvae were used to contaminate representative hive materials. Field strains were previously isolated from bee products and identified by PCR technique. Stock cultures of test strains were passaged onto
Columbia sheep blood agar (Liofilchem, Roseto Degli Abruzzi, Italy) and incubated at $35^{\circ} \mathrm{C}$ and $5 \%$ $\mathrm{CO}_{2}$ as approximately $80 \%$ of cells were sporulated. Sporulation was checked by staining with malachite green and microscopic examination. Spore suspensions were prepared by transferring of the sporulated colonies from agar surface into distilled water and resulted suspensions were pooled in the same tube to obtain a spore cocktail of three strains. The pooled suspension was centrifuged and resuspended in sterile distilled water. Then, spore concentration of the suspension was determined on Columbia sheep blood agar by plate count technique and adjusted to $10^{7}$ spores $/ \mathrm{mL}$ with sterile distilled water. The final suspension was used as inoculum and refrigerated until used. It was heated at $80^{\circ} \mathrm{C}$ for 10 min to eliminate vegetative cells and activate spores before inoculation of hive materials.

\section{Inoculation of hive materials}

Untreated pinewood and polyvinyl chloride (PVC) were chosen as representative for wooden and plastic hive materials. Totally 30 small sticks $(7 \times 3 \times 2.5$ $\mathrm{cm})$ of each material, sterilized under ultra violet light, were arranged on an aluminum foil. Then, about $10 \mathrm{~mL}$ of the pooled spore suspension, supplemented with $0.5 \mathrm{~mL}$ Tween 80 (Merck, Darmstadt, Germany) in order to increase wettability [22], was transferred into an atomizer (DeVilbiss Healthcare, Somerset, PA, USA) and sprayed as homogeneously as possible on the sticks. After inoculation, sticks were remained for $30 \mathrm{~min}$ to dry and inoculated sticks were refrigerated until ozone treatment.

\section{Ozone treatment}

A 9 L gas-tight plexiglas desiccator (Belart Products, Wayne, NJ, USA) equipped with two gas valves for the air inlet and outlet was used as ozonation chamber. Inoculated sticks were placed into chamber with the inoculated surface uppermost. Each treatment group was comprised of three pinewood or PVC sticks. Inoculated sticks were subjected to two different concentrations of gaseous ozone produced directly from atmospheric oxygen by a labscale generator (Genozon, Denizli, Turkey) with adjustable ozone output. Ozonation was performed for four exposure times (30, 60, 90 and $120 \mathrm{~min})$ at ambient laboratory conditions. 
The ozone concentrations in the air flow produced by the generator were determined as 9.8 and $17.1 \mathrm{mg} / \mathrm{L}$ based on ozone/iodine stoichiometry by the iodometric titration method [15]. Iodometric method was carried out by bubbling of gaseous ozone at a flow rate of $1 \mathrm{~L} / \mathrm{min}$ in a washing bottle equipped with a diffuser containing $200 \mathrm{~mL}$ buffered potassium iodide (KI) solution. After bubbling of KI solution, $\mathrm{pH}$ was lowered to 2 with sulfuric acid $(4.5 \mathrm{~mol} / \mathrm{L})$, in order to complete the reaction. Immediately after, the liberated iodine was titrated to a starch endpoint with freshly standardized sodium thiosulfate solution $(0.1 \mathrm{~mol} / \mathrm{L})$. The times required to reach asymptotic concentrations of ozone in the treatment chamber were calculated by a mass balance equation previously described by Silva et al. [26]:

$$
C_{0} \times\left(1-e^{\left(-1-\frac{t}{V_{i}}\right)}\right)=C
$$

where $C_{0}$ is the concentration of ozone in air flow $(\mathrm{mg} / \mathrm{L}), v$ is the rate of air flow $(\mathrm{L} /$ $\min ), t$ is the time ( $\mathrm{min}), V_{t}$ is the volume of treatment chamber (L) and $C$ is the predicted ozone concentration in the chamber for specified time $(\mathrm{mg} / \mathrm{L})$.

\section{Enumeration of $P$. larvae}

Enumeration of $P$. larvae on inoculated sticks before and after ozone exposure was performed by plate count technique. The sticks were aseptically transferred to the sterile stomacher bags containing $200 \mathrm{~mL}$ of maximum recovery diluent (Lab M, Bury, UK) supplemented with Tween 20 at $1 \%$. Then bags were hand shaken vigorously for $10 \mathrm{~min}$ to release spores from sticks. Additional ten-fold dilutions were made by maximum recovery diluent. Totally $1 \mathrm{~mL}$ of initial suspensions and ten-fold dilutions were surface plated on three Columbia sheep blood agar plates. After incubation at $35^{\circ} \mathrm{C}$ and $5 \%$ $\mathrm{CO}_{2}$ for 4 days, the $P$. larvae colonies were counted and results were determined as $\log \mathrm{cfu} / \mathrm{stick}$.

\section{Statistical Analyses}

Results obtained from three independent trials were analyzed by Levene's and Shapiro-Wilk tests to check the homogeneity of the variances and normality, respectively. One-way analysis of variance was used to compare the differences between groups. The Bonferroni correction method, a multiple comparison test, was used for a post hoc comparison at $p<0.05$. The data were evaluated via SPPS 20 (IBM Corp., Armonk, NY, USA).

\section{Results}

According to the concentration curves constructed by the results of mass balance equation, the durations required to reach the asymptotic concentrations of ozone $(9.8$ and $17.1 \mathrm{mg} / \mathrm{L})$ in the treatment chamber were less than 50 min (Figure 1).

The reductions in the level of $P$. larvae spores on ozonated pinewood and PVC sticks during 120 min of treatment are shown in Table 1 and Table 2 , respectively. Initial inoculation levels on pinewood and PVC sticks were determined as 6.5 and $6.6 \mathrm{log} \mathrm{cfu} / \mathrm{stick}$, respectively. After $120 \mathrm{~min}$ of treatment, spore population on pinewood sticks was significantly $(p<0.05)$ reduced by 1.6 and $2.3 \mathrm{log}$ at ozone concentrations of 9.8 and $17.1 \mathrm{mg} / \mathrm{L}$, respectively. These reduction levels were exceeded on PVC sticks after 90 min of ozonation. Reductions of 2.9 and $4.1 \log$ were observed in the counts of $P$. larvae spores on PVC when the sticks were treated for $120 \mathrm{~min}$ at 9.8 and $17.1 \mathrm{mg} / \mathrm{L}$, respectively. Enumeration results indicated that reductions in the levels of $P$. larvae spores on PVC sticks after 90 and 120 min were significantly $(p<0.05)$ higher than those on pinewood sticks.

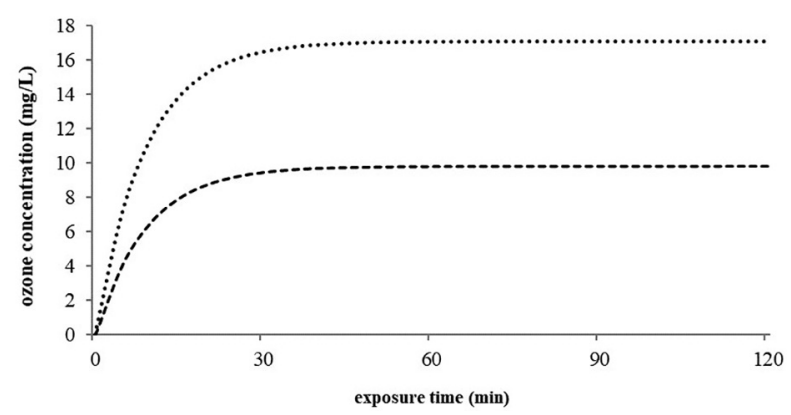

Figure 1. Predicted ozone concentrations in the chamber during the treatments: ---- $9.8 \mathrm{mg} / \mathrm{L},----17.1 \mathrm{mg} / \mathrm{L}$.

Table 1. Viable population of Paenibacillus larvae spores on pinewood sticks during ozonation $( \pm$ standard deviations, $\log \mathrm{cfu} / \mathrm{stick})$.

\begin{tabular}{|c|c|c|c|c|c|}
\hline \multirow{2}{*}{$\begin{array}{l}\text { Ozone } \\
\text { concentration } \\
(\mathrm{mg} / \mathrm{L})\end{array}$} & \multicolumn{5}{|c|}{ Treatment time (min) } \\
\hline & $\mathbf{0}$ & 30 & 60 & 90 & 120 \\
\hline 9.8 & $6.5 \pm 0.2^{\mathrm{a}}$ & $6.3 \pm 0.2^{\mathrm{a}}$ & $5.9 \pm 0.3^{\mathrm{ab}}$ & $5.4 \pm 0.5^{\mathrm{ab}}$ & $4.9 \pm 0.2^{b}$ \\
\hline 17.1 & $6.5 \pm 0.2^{\mathrm{a}}$ & $6.2 \pm 0.3^{\mathrm{a}}$ & $5.6 \pm 0.5^{\mathrm{ab}}$ & $4.9 \pm 0.3^{\mathrm{bc}}$ & $4.2 \pm 0.3^{\mathrm{c}}$ \\
\hline
\end{tabular}

${ }^{\text {ab }}$ Values followed by the same letter in the same row are not significantly different $(\mathrm{p}<0.05)$. 
Table 2. Viable population of Paenibacillus larvae spores on PVC sticks during ozonation ( \pm standard deviations, $\log \mathrm{cfu} / \mathrm{stick})$.

\begin{tabular}{lccccc}
\hline $\begin{array}{l}\text { Ozone } \\
\text { concentration } \\
(\mathbf{m g} / \mathbf{L})\end{array}$ & $\mathbf{0}$ & $\mathbf{3 0}$ & $\mathbf{6 0}$ & $\mathbf{9 0}$ & $\mathbf{1 2 0}$ \\
\cline { 2 - 6 } & $6.6 \pm 0.2^{\mathrm{a}}$ & $6.2 \pm 0.4^{\mathrm{ab}}$ & $5.6 \pm 0.3^{\mathrm{b}}$ & $4.6 \pm 0.4^{\mathrm{c}}$ & $3.7 \pm 0.5^{\mathrm{c}}$ \\
\hline 9.8 & $6.6 \pm 0.2^{\mathrm{a}}$ & $6.2 \pm 0.2^{\mathrm{a}}$ & $5.1 \pm 0.4^{\mathrm{b}}$ & $3.8 \pm 0.3^{\mathrm{c}}$ & $2.5 \pm 0.5^{\mathrm{d}}$ \\
\hline 17.1 & ${ }^{2}$ &
\end{tabular}

ab Values followed by the same letter in the same row are not significantly different $(p<0.05)$.

\section{Discussion}

Ozone in gaseous state has been successfully utilized for inactivation of bacterial spores both in their suspensions and on different types of materials including glass, plastic, stainless steel and wood $[3,5,18]$. In this work, we observed the reduction in viability of $P$. larvae spores on hive materials up to $4.1 \mathrm{log}$, as a result of exposure to gaseous ozone. However, it should be noted that the antimicrobial effect of ozone against bacterial species is influenced by the physiological state and structural properties of the bacterium, and spores are generally more resistant to oxidizing effects compared to their vegetative counterparts $[12,24]$. In accordance with our results, James [16] reported that cadavers of honey bee larvae infected with $P$. larvae were effectively sterilized with ozonation at $0.9 \mathrm{mg} / \mathrm{L}$ in combination with elevated temperature $\left(50^{\circ} \mathrm{C}\right)$ and relative humidity (75\%). In the study of Khadre and Yousef [19], the sporicidal action of ozone was compared with hydrogen peroxide in spore suspensions of Bacillus species. Their results demonstrated that ozone at $11 \mathrm{mg} / \mathrm{L}$ was more effective than $10 \%(\mathrm{v} / \mathrm{v})$ concentration of hydrogen peroxide.

Sporicidal activity of ozone can be explained by a complex and progressive oxidative process that affects outer spore components such as spore coat and inner membrane [28]. The outer spore coat layers were identified as a probable site of action of ozone in the electron microscopic study of ozonetreated Bacillus subtilis spores [19]. Specific effect of ozone against spore's inner membrane can be attributed to oxidation of unsaturated fatty acids and membrane proteins. Young and Setlow [28] suggested that ozone does not kill spores by DNA damage but rather by damaging the ability of the spores to germinate. They also suggested that dam- age to the inner membrane of spores causes defects in spore germination. Apart from the damage to the outer layers of the spore, gaseous ozone may also penetrate into the spore core and inactivate various vital cellular components including critical core enzymes and proteins $[12,17,21]$.

The main challenge in ozonation of wooden materials for the purpose of decontamination is their porous structure. When materials possessing porous surface, the spores can penetrate and embed into cavities of the test material. Embedding of spores into the test materials could preclude the interaction of gaseous disinfectants with the spores, thereby decreasing their potential for spore inactivation. Therefore, it can be suggested that sporicidal efficacy of gaseous disinfectants like ozone on different materials is significantly affected by the surface porosity. Similar to our results, previous studies reported that the reductions observed on wooden materials after treatment with gaseous disinfectants including ozone were considerably lower than on nonporous materials such as plastics $[4,25]$.

The results obtained from this study suggest that gaseous ozone treatment is a promising alternative to current decontamination methods especially for plastic hives. Complete elimination of $P$. larvae spores from hive materials is a requirement to prevent the spread and recurrence of the AFB. Therefore, additional validation studies are still needed to achieve more reduction in the counts of $P$. larvae spores on hive materials.

\section{References}

1. Achen M, Yousef AE, (2001). Efficacy of ozone against Escherichia coli $\mathrm{O} 157: \mathrm{H7}$ on apples. J Food Safety. 66, 1380-1384.

2. Alonso-Salces RM, Cugnata NM, Guaspari E, Pellegrini MC, Aubone I, De Piano FG, Antunez K, Fuselli SR, (2017). Natural strategies for the control of Paenibacillus larvae, the causative agent of American foulbrood in honey bees: a review. Apidologie. 48, 387-400.

3. Aydogan A, Gurol MD, (2006). Application of gaseous ozone for inactivation of Bacillus subtilis spores. J Air Waste Manage. 56, 179-185.

4. Cullen PJ, Norton T, (2012). Ozone sanitation in the food industry. O'Donnell C, Tiwari BK, Cullen PJ, Rice CRG. eds. Ozone in Food Processing, A John Wiley \& Sons Ltd., Oxford. p. 163-176. 
5. De Candia S, Morea M, Baruzzi F, (2015). Eradication of high viable loads of Listeria monocytogenes contaminating food-contact surfaces. Front Microbiol. 6, 1-12.

6. De Guzman ZM, Cervancia CR, Dimasuay KG, Tolentino MM, Abrera GB, Cobar ML, Fajardo AC, Sabino NG, Manila-Fajardo AC, Feliciano CP, (2011). Radiation inactivation of Paenibacillus larvae and sterilization of American Foul Brood (AFB) infected hives using Co-60 gamma rays. Appl Radiat Isot. 69, 1374-1379.

7. Del Hoyo M, Basualdo M, Torres J, Bedascarrasbure E, (1998). Use of DHT-equipment for disinfection of AFBcontaminated beehive materials in Argentina. Am Bee J. 138, 738-740.

8. Dobbelaere W, De Graaf DC, Reybroeck W, Desmedt E, Peeters JE, Jacobs FJ, (2001). Disinfection of wooden structures contaminated with Paenibacillus larvae subsp. larvae spores. J Appl Microbiol. 91, 212-216.

9. FERA, (2013). Hive cleaning and sterilization. Food and Environment Research Agency, York.

10. Genersch E, (2017). Foulbrood diseases of honey beesfrom science to practice. Vreeland RH, Sammataro D. eds. Beekeeping-From Science to Practice, Springer, Cham. p. 157-174.

11. Genersch E, Forsgren E, Pentikäinen J, Ashiralieva A, Rauch S, Kilwinski J, Fries I, (2006). Reclassification of Paenibacillus larvae subsp. pulvifaciens and Paenibacillus larvae subsp. larvae as Paenibacillus larvae without subspecies differentiation. Int J Syst Evol Microbiol. 56, 501511.

12. Guzel-Seydim ZB, Greene AK, Seydim AC, (2004). Use of ozone in the food industry. LWT-Food Sci Technol. 37, 453-460.

13. Hasemann L, (1961). How long can spores of American foulbrood live? Am Bee J. 101, 298-299.

14. Hitchcock JD, Stoner A, Wilson WT, Menapace DM, (1979). Pathogenicity of Bacillus pulvifaciens to honeybee larvae of various ages (Hymenoptera: Apidae). J. Kansas Entomol Soc. 52: 238-246.

15. IOA, (1996). Quality assurance committee revised standardized procedure 001/96. International Ozone Association, Scottsdale.

16. James RR, (2011). Potential of ozone as a fumigant to control pests in honey bee (Hymenoptera: Apidae) hives. J Econ Entomol. 104, 353-359.
17. Kasler D, Yousef AE, (2017). Antimicrobial gases for food application. Juneja VK, Dwivedi HP, Sofos JN. eds. Microbial Control and Food Preservation, Springer, New York. p. 327-348.

18. Khadre MA, Yousef AE, (2001a). Decontamination of a multilaminated aseptic food packaging material and stainless steel by ozone. J. Food Safety. 21, 1-13.

19. Khadre MA, Yousef AE, (2001b). Sporicidal action of ozone and hydrogen peroxide: A comparative study. Int J Food Microbiol. 71, 131-138.

20. Lauro FM, Favaretto M, Covolo L, Rassu M, Bertoloni G, (2003). Rapid detection of Paenibacillus larvae from honey and hive samples with a novel nested PCR protocol. Int J Food Microbiol. 81, 195-201.

21. Mudd JB, Leavitt R, Ongun A, McManus TT, (1969). Reaction of ozone with amino acids and proteins. Atmos Environ. 3, 669-682.

22. Nascimento MS, Brum DM, Pena PO, Berto MI, Efraim $\mathrm{P}$, (2012). Inactivation of Salmonella during cocoa roasting and chocolate conching. Int J Food Microbiol. 159, 225229.

23. Patil S, Cullen PJ, Bourke P, (2014). Ozone: a novel microbial inactivation process. Boziaris IS. ed. Novel Food Preservation and Microbial Assessment Techniques, CRC Press, London. p. 126-154.

24. Restaino L, Frampton EW, Hemphill JB, Palnikar P, (1995). Efficacy of ozonated water against various food-related microorganisms. Appl Environ Microbiol. 61, 3471-3475.

25. Rogers JV, Sabourin CLK, Choi YW, Richter WR, Rudnicki DC, Riggs KB, Taylor ML, Chang J, (2005). Decontamination assessment of Bacillus anthracis, Bacillus subtilis, and Geobacillus stearothermophilus spores on indoor surfaces using a hydrogen peroxide gas generator. J Appl Microbiol. 99, 739-748.

26. Silva MV, Gibbs PA, Kirby RM, (1998). Sensorial and microbial effects of gaseous ozone on fresh scad (Trachurus trachurus). J Appl Microbiol. 84, 802-810.

27. Wilson WT, (1971). Resistance to American foulbrood in honey bees: XI. Fate of Bacillus larvae spores ingested by adults. J Invertebr Pathol. 17, 247-255.

28. Young SB, Setlow P, (2004). Mechanisms of Bacillus subtilis spore resistance to and killing by aqueous ozone. J App Microbiol. 96, 1133-1142. 